\title{
研究課題別事後評価結果
}

1. 研究課題名「運動の学習制御における小脳機能の解明」

2. 研究代表者名及び主たる研究参加者名（研究機関名・職名は研究参加期間終了時点） 研究代表者永雄 総一 （自治医科大学医学部 助教授）

主たる研究参加者

$\begin{array}{llll}\text { 藤田 } & \text { 昌彦 } & \text { (法政大学工学部 教授) } \\ \text { 系原 } & \text { 重美 } & \text { (理研脳科学総合研究センター チームリーダー) } \\ \text { 柳原 } & 大 & \text { (豊橋技術科学大学体育保健センター 助教授 }) \\ \text { 板東 } & \text { 武彦 } & \text { (新潟大学医学部第一生理 教授） } \\ \text { 山口 } & \text { 和彦 } & \text { (理研脳科学総合研究センター 副チームリーダー) } \\ \text { 山田 } & \text { 仁三 } & \text { (東京医科大学第二解剖 教授 })\end{array}$

3. 研究内容及び成果：

小脳は運動学習に関与している。しかしその具体的なメカニズムについては、二つの対 立する仮説が提出され 20 年間にわたり論争が続き脳研究の大きなトピックスとなってい た。その一つは、長期抑圧 (LTD) と呼ばれる小脳のシナプス伝達可塑性が運動学習の原因で あるという Marr-Albus-伊藤の仮説であり、それに対立しているのが、運動学習の源は小 脳以外にあり、小脳はそれに必要な信号源としての副次的役割を演じているという Lisberger らの考え方である。本研究は、計算論的なモデルと実験研究との密接な協調によ り、小脳における運動学習の機構を明らかにすることでこの問題を解決し、さらに高次の 脳の学習機構解明への新しい突破口を切り拓くことを目指した。

まず両仮説で結果の異なる具体的な実験事実を再検討し、その争因を明らかにするとと もに、さらに新しい実験パラダイムを開発し、小脳における運動学習の機構を明らかにし た。その上で、運動学習に短期記憶と長期記憶の二つのシステムがあることを発見するこ とで、問題を根本的に解決した。さらに、大脳皮質一小脳連関がメインとなる随意運動や 認知学習に、従来の反射や条件付けのような単純なシステムに関する小脳の研究成果を拡 張できるかどうかを検討した。そのために、生理および心理実験パラダイムを作成し、そ れに関与する神経回路網を新たに同定し、その中での長期抑圧の位置付けを検討した。ま た、生理や心理実験の結果から推定される高次機能における小脳の学習制御のアルゴリズ ムが工学的に実証可能かどうかを、具体的な運動モデルを設定して理論付けをした。以下 に各サブグループの役割と成果を述べる。

永雄を中心とする自治医大サブグループは、本研究の中核をなすもので、他のサブグル ープの協力を仰ぎつつ、小脳における運動学習の長期抑圧（LTD）の役割を総合的に明らか にした。すなわち、前庭動眼反射および随意運動制御のいずれにおいても、数時間から十 数時間における運動学習の記憶が小脳皮質における長期抑圧の仕組みより保持されている ことを具体的に明らかにすることに成功した。これは、猿とマウスにおいて、適応が生じ た直後の片葉を局所麻酔剤により遮断することにより記憶が消失すること、LTD が遺伝的に 消失している遺伝子操作マウスを用いた実験など、巧妙にして精密かつ信頼性の高い実験 
研究に支えられている。

しかし、運動学習には短期と長期のものがあり、それぞれ異なった特徵を持つ。長期と は、一日を超える期間の記憶の保持である。これを明らかにするために、マウスを使って 運動学習の実験パラダイムを新たに開発し、LTD と小脳の役割を検討した。すなわち、マウ スに 1 日 1 時間の訓練を行うと、視機性眼球反応の利得に短期の適応が生じる。この短期 の適応は 24 時間以内に消失するが、訓練を 4-5 日にわたり毎日行うと、訓練を行う前の利 得が徐々に増加し長期の適応が生じる。このパラダイムにより、数時間単位でおこる短期 の学習と、数日から 1 週間の単位でおこる長期の学習を分離して定量評価できるようにな った。この結果、視機性眼球反応の長期適応の記憶は小脳核に相当する前庭神経核に貯え られていることを初めて明らかにした。

これらの所見を総合すると、学習記憶に関し、小脳皮質に LTD によって短期運動学習の 記憶がまず形成され、訓練が長期間にわたると、何らかのメカニズムが作用して二次的に 小脳皮質の出力先の小脳（前庭）核に長期記憶が生成されることが解明された。

藤田を中心とする法政大学のサブグループは計算論モデルを構成し、これを解析するこ とで、小脳の運動学習の理論モデルを建設した。とくに、サッケード眼球運動系における 文脈依存性学習及び遅延学習が運動に先行する形で起こることを見出した。本サブグルー プの寄与は、記憶誘導性サッケードにおいても step-back 型適応が生じることを見出した こと、これが他の視覚誘導性サッケードの適応に対して一定の独立性を持つことを示した ことである。

さらに、LTD をベースにした視覚誘導性サッケード眼球運動適応の理論を構成することに 成功した。これまで、LTD をべースにしたサッケード学習系の理論的枠組みは提供されてお らず、これがネックとなって実験の進め方、実験データの解釈が混迷していた。これを解 決すべく、四つの基礎仮説をべースにして、サッケード適応の空間的特性、時間的特性を、 これまでの生理学、解剖学データを首尾一貫した論理で説明することに成功している。

このほか、新潟大の板東サブグループは、PET、fMRI を用いた行動実験科学で、理研に おける糸原および山口両サブグループは長期抑圧に関係する遺伝子探索およびその分子メ カニズムで、豊橋技科大の柳原サブグループは生体リズムの形成にかかわる学習で、東京 医大の山田サブグループは小脳一大脳連関神経回路の同定で、それぞれ優れた成果を生み 出し、本研究の実質的なサポートを行っている。

\section{4. 事後評価結果}

$4-1$. 外部発表 (論文、口頭発表等)、特許、研究を通じての新たな知見の取得等の研究 成果の状況

小脳のシナプス長期抑圧は、海馬の長期増強とともに学習記憶の基礎となる基本的な現 象である。しかるに小脳における運動学習のメカニズムについては、これまでに二つの見 解が対立していた。本研究は、理論、行動、生理、遺伝子レベルの研究を総合して学習の メカニズムを明らかにし、運動学習は学習に短期にかかわる部位とそれを転移して長期に 保持する部位に分けられ、それらが別々に存在することを実証して、この対立を高次の視 点から解決した。また、随意運動における大脳一小脳連関とその小脳の学習メカニズムに ついても、優れたモデルを立てることにより合わせて統一的に明らかにすることに成功し 
ている。

これらの成果は海外 54 件国内 9 件に及ぶ論文発表、国内外 103 件の学会発表からも明ら かである。しかし、最終的な成果は研究の最終段階で得られたため、主要な成果の発表は さらにこれからになるが、その影響するところは大きく、その反響を見るのが楽しみであ る。

$4-2$. 成果の戦略目標・科学技術への貢献

本研究は学術的基礎的なものであるが、脳の記憶と学習にかかわる本質を突いたもので ある。とくに、記憶の短期的な保存と長期的な保存とが異なる部位で起こることを明らか にしたことは、つぎにその転移の仕組みを解明するという新たな課題を突きつける。この 意味で、本研究はシステム脳科学のみならず、その分子メカニズムの解明にも、新たな問 題を投げかけ、これからの大きな飛躍のきっかけを築いたものといえる。

このために本研究は分子、行動、回路、理論、脳測定と広い範囲の研究者および研究方 法を融合する学際的なアプローチをとることにより成功したもので、これからの研究の進 め方に大きな示唆を与えるものでもある。

$4-3$ ．その他の特記事項

本研究は、主として研究代表者の総合的な構想と、これを支える理論、分子、行動にか かわる研究者との連携によって行われた。実験研究での成果はこれからの研究方向に多大 な影響を与える優れたものである。また、理論研究も独自の視点から、優れたモデルと仮 説を与え、大きく評価できる。

しかし、理論が仮説を立て、これが主導して実験の設計が行われる、もしくは実験事実 に即した理論形成が行われるという意味での融合はさほど見られず、どちらからといえば、 両者が刺激しあいながら並行に研究が進んだといえる。この点では今後に課題を残した。 